\title{
Drip Irrigation Elevated Olive Productivity in Southwest China
}

\author{
Quan Liu ${ }^{1}$, Yan Lan ${ }^{1}$, Feng Tan ${ }^{1}$, Yunbiao $\mathrm{Tu}^{1}$, Yingying Sun ${ }^{1}$, \\ Gajue Yougu ${ }^{2}$, Zeshen Yang ${ }^{2}$, Chunbang Ding ${ }^{3}$, and Tian $\mathrm{Li}^{1,4,5}$
}

AdDitional INDEX wORDs. fruit set, oil content, Olea europaea, perfect flower, shoot growth, yield

Summary. Water is essential for crops and plays a vital role in olive (Olea europaea) growth. Three irrigation treatments, rain-fed (CK), flood irrigation (FI), and drip irrigation (DI), were applied from late November to late May in a 2-year study (Nov. 2015 to Oct. 2017) on two olive cultivars, Coratina and Koroneiki. Shoot growth, flower and fruit characteristics, and olive and oil yields were measured. Compared with CK, FI had significantly higher values of vegetative growth, olive and oil yields, moisture content, and oil content. Although the fruit weight, pulp rate, and oil content with DI were the lowest, our results support that DI had the greatest positive effects on olive vegetative growth, flowers, fruit set, and olive and oil yields. It is suggested that DI in winter and spring is the best irrigation strategy for olive productivity in southwest China.

$\mathrm{O}$ live is commonly used to extract olive oil by mechanical means and is mainly grown in Mediterranean coastal areas (Carrasco-Pancorbo et al., 2015; Vossen, 2007). The global consumption of olive oil has increased by $63 \%$ over the past 26 years because of its high nutritional value and associated health benefits [International Olive Council (IOC), 2018]. Accompanying the global increase in olive oil consumption, improving the production of olive oil became a focus issue for global researchers and producers (Suematsu et al., 2006). In China, the olive oil imports in 2014 were seven times more than that in 2004 (IOC, $2016,2018)$. China started introducing and planting olive trees in the

Received for publication 29 Oct. 2018. Accepted for publication 21 Dec. 2018.

Published online 15 February 2019.

${ }^{1}$ College of Agronomy, Sichuan Agricultural University, No. 211, Huimin Rd, Wenjiang District, Chengdu City, Sichuan 611130, P.R. China

${ }^{2}$ Lianshan Zhongze New Technology Development Co., Ltd., Nanhua Tower, Chang'an East Rd, Xichang City, Sichuan 615000, P.R. China

${ }^{3}$ College of Life Science, Sichuan Agricultural University, No. 46, Xinkang Road, Yucheng District, Ya'an City, Sichuan 625014, P.R. China

${ }^{4}$ College of Water Conservancy and Hydropwer Engineering, Sichuan Agricultural University, No. 46, Xinkang Rd, Yucheng District, Ya'an City, Sichuan 625014, P.R. China

${ }^{5}$ Corresponding author. E-mail: lit@sicau.edu.cn.

This is an open access article distributed under the CC BY-NC-ND license (https://creativecommons.org/ licenses/by-nc-nd/4.0/).

https://doi.org/10.21273/HORTTECH04211-18 1960s (Cheng et al., 2017). After decades of exploration, Chinese scientists have reached a consensus that the most suitable regions for olive production in China are two areas: 1) the dry and hot valley zone of Jinsha River area (Yongsheng, Yongren, and Xichang); and 2) the area between the south slope of West Qinling Mountains and the low mountain valley of Bailong River (Wudu) (Shi et al., 2011; Su et al., 2018). China started to expand its olive area in the early years of the 21 st century and now has $\approx 86,000$ ha (IOC, 2016), mainly distributed in southwest (Sichuan, Yunnan, and Chongqing) and northwest China (Gansu and Shaanxi) (Su et al., 2018). Sichuan, especially Xichang [located in Jinsha River area (area 1)], has the best climatic conditions to develop the olive industry, and oil content of olives from this region can reach 28\% (Xiao et al., 2009).

Olive is a drought-resistant plant. In general, the traditional olive orchards in Mediterranean areas are under rain-fed conditions without any form of irrigation (Sofo et al., 2008). However, in modern intensive orchards, more trees are planted per hectare than are in traditional orchards, which leads to decreased water availability for individual olive trees at a specific area with a relatively stable amount of rainfall (Fernández and Moreno, 1999). As a consequence, olive growth, including vegetative growth (the basis for flowering and cropping in the next year), flower-bud formation, and fruit development, could be limited by water shortage (Gucci et al., 2009; Hartmann, 1950; Masmoudi-Charfi and Mechlia, 2008). Studies have shown that irrigation during summer and autumn in a Mediterranean climate is an effective way to increase olive productivity (Hijazi et al., 2014; Proietti and Antognozzi, 1996; SanzCortés et al., 2015). In the main growing area in the Jinsha River area in southwest China, there is almost no rainfall during winter and spring, which greatly constrains the vernalization and bloom of olive trees (Denney et al., 1985; Liu and Sun, 2013; Sanz-Cortés et al., 2015). In recent years, most of the olive trees in Sichuan have been planted in the mountains (Guo et al., 2010), and DI has been applied in the modern intensive olive orchards to replace traditional FI. However, little is known about the effects on olive productivity of different irrigation strategies in China. Therefore, a 2-year field study was conducted 1 ) to investigate olive productivity under FI and DI compared with CK during olive growth and development periods and 2) to determine a better irrigation strategy for improving olive production in the main suitable growing area in China.

\begin{tabular}{llll}
\hline $\begin{array}{l}\text { Units } \\
\text { To convert U.S. to SI, } \\
\text { multiply by }\end{array}$ & U.S. unit & SI unit & $\begin{array}{l}\text { To convert SI to U.S., } \\
\text { multiply by }\end{array}$ \\
\hline 0.4047 & $\mathrm{acre}(\mathrm{s})$ & $\mathrm{ha}$ & 2.4711 \\
0.3048 & $\mathrm{ft}$ & $\mathrm{m}$ & 3.2808 \\
3.7854 & $\mathrm{gal}$ & $\mathrm{L}$ & 0.2642 \\
2.54 & inch $(\mathrm{es})$ & $\mathrm{cm}$ & 0.3937 \\
25.4 & inch(es) & $\mathrm{mm}$ & 0.0394 \\
0.4536 & $\mathrm{lb}$ & $\mathrm{kg}$ & 2.2046 \\
28.3495 & $\mathrm{Oz}$ & $\mathrm{g}$ & 0.0353 \\
1 & $\mathrm{ppm}$ & $\mathrm{mg} \cdot \mathrm{kg}^{-1}$ & 1 \\
$\left({ }^{\circ} \mathrm{F}-32\right) \div 1.8$ & ${ }^{\circ} \mathrm{F}$ & ${ }^{\circ} \mathrm{C}$ & $\left({ }^{\circ} \mathrm{C} \times 1.8\right)+32$ \\
& & &
\end{tabular}




\section{Materials and methods}

Field site AND experimental MATERIAL. The field trial was conducted during two consecutive seasons (Nov. 2015 to Oct. 2017) at Beihe Olive Commercial Orchard (lat. $27^{\circ} 44^{\prime} \mathrm{N}$, long. $102^{\circ} 14^{\prime} \mathrm{E}$, elevation $1590 \mathrm{~m}$ ) of Liangshan Zhongze New Technology Development Co., Ltd., which is located in Xixi village, Xichang City, Sichuan Province, southwest China. The soil texture of the orchard was red clay loam with a $\mathrm{pH}$ value of 6.2 (0 to 30 $\mathrm{cm}$ depth, $1.85 \%$ of organic matter, $110.12 \mathrm{mg} \cdot \mathrm{kg}^{-1}$ of available nitrogen, $61.29 \mathrm{mg} \cdot \mathrm{kg}^{-1}$ of available phosphorous, and $95.14 \mathrm{mg} \cdot \mathrm{kg}^{-1}$ of available potassium K). Meteorological data (Fig. 1) were obtained from the $\mathrm{Na}$ tional Meteorological Information Center, China (China Meteorological Administration, 2017). The climate was characterized by dry winter and wet summer, and more than $80 \%$ of the annual precipitation occurred in summer and autumn (Fig. 1B). The total annual precipitation, evapotranspiration, and sunshine duration were $1072.8 \mathrm{~mm}, 1001.8 \mathrm{~mm}$, and $2218.7 \mathrm{~h}$ in the first season, whereas they were $1227.4 \mathrm{~mm}, 972.6 \mathrm{~mm}$, and $2257.4 \mathrm{~h}$ the following season, respectively. The annual average temperature in the trial period was $17.6^{\circ} \mathrm{C}$, with the lowest temperature was usually in January $\left(-1.7{ }^{\circ} \mathrm{C}\right)$, whereas the highest was in May $\left(35.2{ }^{\circ} \mathrm{C}\right)$, and the annual lowest and highest were 13.1 and $24.3{ }^{\circ} \mathrm{C}$, respectively (Fig. 1A).

EXPERIMENTAL DESIGN. Two widely distributed olive cultivars in
China, Coratina and Koroneiki, were selected for the experiment. The trees were planted in 2007 at distances of $4.5 \times 4 \mathrm{~m}(556$ trees $/ \mathrm{ha})$. The experimental orchard was divided into three blocks each containing three plots, and each plot was $\approx 0.3$ ha with 150 trees ( 10 rows $\times 15$ trees $)$ and comprised two equivalent subplots. One subplot was cultivar Coratina, and the other was Koroneiki. Two central trees of each cultivar with flower buds in each subplot were used for all field measurements and sampling analysis, and the others were considered as guard trees. In Sept. 2015, a DI system was installed in three plots (one plot in each block) with two drippers $\left(2.0 \mathrm{~L} \cdot \mathrm{h}^{-1}\right)$ per tree. The irrigation experimental set up was a single factor randomized block design. Three treatments of different irrigation strategies, CK (nonirrigated), FI, and DI were applied in these nine plots. The trees in treatments of FI and DI received the same amount of fresh water three times per week from late November to the first notable rainfall (a total daily precipitation of more than $20 \mathrm{~mm}$, usually in late May). During the two seasons (2015-16, and 2016-17), the total quantities of applied water to each tree were $\approx 246$ and $228 \mathrm{~mm}$, respectively. All other cultivation management (including fertilization, pruning, and control of weeds, diseases, and pests) followed the common practices used in the orchard. Table 1 presents the applied fertilization details during two crop seasons (2015-16 and 2016-17) for each irrigation treatment.
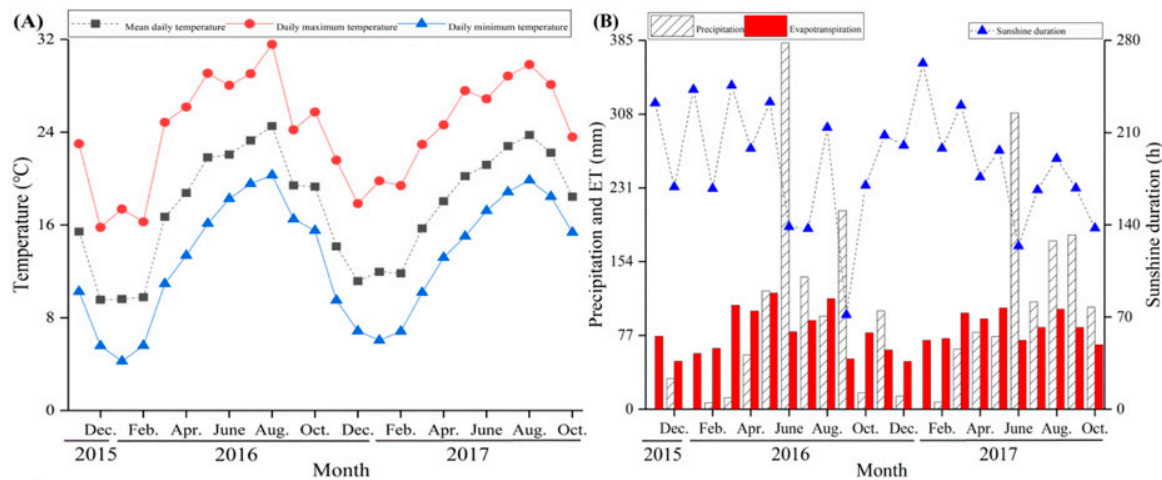

Fig. 1. Seasonal trends in climate during two olive crop seasons (2015-16 and 2016-17): (A) mean daily temperature, daily maximum temperature, and daily minimum temperature; (B) precipitation, evapotranspiration (ET), and sunshine duration; $\left({ }^{\circ} \mathrm{C} \times 1.8\right)+32={ }^{\circ} \mathrm{F}, 1 \mathrm{~mm}=0.0394$ inch.
F I E L D S A M P L I N G A N D MEASUREMENTS. Four branches with flower buds and new apical shoots from the four directions (east, south, west, and north) in each sampling tree were labeled at the end of March for field survey. The shoot length, number of shoots with inflorescences, and florets to inflorescence, were measured in preselected branches. From late April to late October, the growth of shoots was measured every month. During the flowering stage, the number of perfect flowers was recorded. The fruits on the branches were counted $60 \mathrm{~d}$ after full bloom (DAFB). The length of tested shoots in each month (from April to October), average number of inflorescences and flowers per shoot were calculated. The rates of perfect flowers and fruit set were determined based on the total number of flowers.

Forty olive fruits from each sampling tree were collected randomly at regular intervals $(30 \mathrm{~d})$ by hand at a height of greater than $1.5 \mathrm{~m}$ outside of the canopy after the pit hardening stage from June to October (75-195 DAFB). Twenty olives were weighed and then dried in a forced-air oven at $105^{\circ} \mathrm{C}$ for $24 \mathrm{~h}$, and the others were used for weighing the stone. Moisture content and pulp rate of fresh fruit were calculated. The dried olives were crushed and packed in a filter paper bag, then put into a Soxhlet extraction apparatus with petroleum ether (boiling point: 30 to $60^{\circ} \mathrm{C}$ ) for 8 to 10 h (Bengana et al., 2013). Fruit oil content was calculated by weighing the paper bag before and after extraction. The percentage value of oil content was expressed on a dry weight basis.

At the end of October, all fruits in the sampling trees were removed and weighed to calculate the olive yield of each tested tree (including sampling fruits). The oil yield per tree was calculated according to the final sampling moisture and oil contents (195 DAFB).

Statistical analysis. The results were expressed as mean values of six replicates and standard deviation. All statistical analysis was performed using the JMP 10 statistical software (SAS Institute, Cary, NC). Univariate treatments of the data were analyzed and compared by one-way analysis of variance by 
Table 1. Applied fertilization details during two olive crop seasons (2015-16 and 2016-17) for each irrigation treatment [ rain-fed control (CK), flood irrigation (FI), drip irrigation (DI)].

\begin{tabular}{|c|c|c|}
\hline No. & Time & Fertilizers $^{\mathrm{z}}$ \\
\hline 1 & Early Nov. 2015 (and 2016) & $\begin{array}{l}2.0 \mathrm{~kg} \text { of manure per tree were applied to the hole } \\
\text { in the soil }\end{array}$ \\
\hline 2 & Early Mar. 2016 (and 2017) & $\begin{array}{l}0.23 \mathrm{~kg} \text { nitrogen }(\mathrm{N}), 0.10 \mathrm{~kg} \text { phosphorus }(\mathrm{P}) \text { per } \\
\text { tree was applied to the hole in the soil, and } 0.2 \% \\
\text { of available boron was sprayed }\end{array}$ \\
\hline 3 & Early June 2016 (and 2017) & $\begin{array}{l}0.42 \mathrm{~kg} \mathrm{~N}, 0.06 \mathrm{~kg} \mathrm{P} \text {, and } 0.21 \mathrm{~kg} \text { potassium per } \\
\text { tree were applied to the hole in the soil }\end{array}$ \\
\hline
\end{tabular}

${ }^{\mathrm{z}} 1 \mathrm{~kg}=2.2046 \mathrm{lb}$

Tukey-Kramer honestly significant difference test. Differences were considered statistically significant and marked with different lowercase letters when the probability value was less than 0.05 .

\section{Results}

EfFects on olive vegetative GrowTH. As shown in Fig. 2, the shoot increment occurred from April to October in all treatments, being almost linear from April to August, and leveling off toward October. Irrigation positively affected shoot growth. Shoots increments of 'Coratina' and 'Koroneiki' starting in late March in FI and DI were significantly higher than CK. Although the shoot elongation of DI was the highest, no statistical differences were found between FI and DI. It is noteworthy that the shoot increment in CK from April to May was less than in FI and DI, but then its growth rate became similar to shoots in FI and DI from May to October. The shoot elongations of 'Coratina' starting in late March varied from 1.71 to 30.688 $\mathrm{cm}(\mathrm{CK}), 4.00$ to $34.23 \mathrm{~cm}(\mathrm{FI})$, and 4.74 to $36.28 \mathrm{~cm}$ (DI). The shoot growth of 'Koroneiki' starting in late March was longer, ranging from 2.91 to $42.55 \mathrm{~cm}$ (CK), 5.17 to $46.43 \mathrm{~cm}$ (FI), and 5.82 to $47.03 \mathrm{~cm}$ (DI).

EFFeCTS ON OLIVE FLOWERING AND FRUIT SET. Results concerning the olive flower characteristics in the three irrigation treatments during crop years of 2016 and 2017 are shown in Table 2. During the two seasons, compared with CK, FI, and DI caused significant increases of the numbers of inflorescences and flowers per shoot, and the rates of perfect flowers and fruit set. Except for the inflorescence number per shoot of 'Koroneiki', the other flower characteristics and fruit set rates of the two olive cultivars in DI were significantly higher than those in FI.

EFFECTS ON FRESH OLIVE FRUIT WEIGHT, PULP RATE, MOISTURE CONTENT, AND DRIED FRUIT OIL CONTENT. The results of fresh fruit weights of the two cultivars in 2016 and 2017 followed similar trends of fruit development in all treatments (Fig. 3A). Fruit weight increased with time; fruit weight in $\mathrm{CK}$ and FI reached the maximum values at 165 DAFB and dropped slightly at harvest. In contrast, the largest fruit weight of the two olive cultivars in DI was at the last sampling day (195 DAFB). During the development period, fruit weights of 'Coratina' increased by $127.60 \%, 128.38 \%$, and $202.90 \%$ in CK, FI, and DI, respectively. The fruit weights of 'Koroneiki' at harvest were $1.56,1.18$, and 1.43 times as high as those at 75 DAFB in CK, FI, and DI, respectively. The smallest fruit weight was found in DI, which was significantly different from CK and FI from 75 to 165 DAFB. No significant differences in fruit weight were observed between CK and FI during the fruit development of 'Coratina'. The fruit weights of 'Koroneiki' in FI were significantly smaller than that in CK at the last two sampling dates (165 and 195 DAFB). There were no significant differences in fruit weights between DI and FI at harvest.

Similarly to the fresh fruit weights, olive pulp rates (Fig. 3B) increased gradually, being linear at the early stages (75-165 DAFB) and leveling off toward the harvest stage. The pulp rates in DI appeared to be the lowest, and the highest was in CK, but no significant differences of 'Coratina' were found among CK, FI, and DI (except for the first sampling).
For 'Koroneiki', the pulp rates in DI were significantly lower than those in $\mathrm{CK}$ and FI during the middle stages (105-165 DAFB), and no significant differences were noted between CK and FI during most of the time of olive development.

In contrast, olive fruit moisture content (Fig. 3C) decreased during olive development, with an especially sharp reduction from 75 to 105 DAFB, after which the decrease rate slowed gradually. The lowest moisture content was detected in $\mathrm{CK}$ and was only significantly different from those in FI and DI during most of the olive development period ('Coratina'). The moisture content in FI and DI showed no significant difference.

Oil content of dried fruit (Fig. 3D) increased with time, reaching the maximum at the last sampling date. The results of oil content in the three treatments appeared to be close at the first sampling time, but the content in FI was significantly higher than those in CK and DI (105-195 DAFB). For 'Coratina', the oil content in CK was significantly higher than that in DI during the last two samplings (165 and 195 DAFB). However, the oil content of 'Koroneiki' in CK were significantly lower than those in DI during the middle samplings (105 and $135 \mathrm{DAFB}$ ).

EFFECT OF DIFFERENT IRRIGATION STRATEGIES ON YIELDS OF OLIVE FRUIT AND OIL. The olive and oil yields per tree in the three irrigation treatments are shown in Table 3. During the two seasons, compared with the CK, FI and DI showed significant increases in fruit and oil yields, and the yields in DI were significantly higher than those in FI. The maximum olive yields of 'Coratina' and 'Koroneiki' were in DI, which increased by $545.58 \%$ and $649.16 \%$ in contrast to CK and were $85.55 \%$ and $110.54 \%$ higher than those in FI. The yields of the two cultivars per tree in FI were 247.93\% and $255.82 \%$ higher than those in $\mathrm{CK}$. The increment rates of oil production in DI and FI were close to the fruit yields (Table 3 ).

\section{Discussion}

Vegetative growth is the basis for olive productivity. In this study, we found that a low water supply in winter and spring resulted in 
significantly lower shoot growth in CK (from April to May). The growth of new shoots in FI and DI were not significantly different. This indicates that irrigation promotes olive vegetative growth and is not related to irrigation methods. Our results are similar to findings from studies in other countries, which showed that irrigation during the low rainfall season in the Mediterranean climate benefited the vegetative growth of olive trees (Ayoub et al., 2016; Farinelli et al., 2006).

In addition to improving shoot growth, water has an important influence on olive reproductive growth, especially during the periods of floral bud differentiation, bloom, and fruit oil accumulation (Gucci et al., 2009; Hartmann, 1950; Masmoudi-Charfi and Mechlia, 2008). Olive yield will be negatively affected by water shortages during these periods. In the Mediterranean basin, the rainfall during the winter is relatively high and precludes the need to irrigate for olive flowering and subsequent fruit set (Torres et al., 2017). This is different from the climate in southwestern China. In Xichang, little rainfall occurs in winter and spring (Liu and Sun, 2013), the critical period for olive axillary bud to blooming

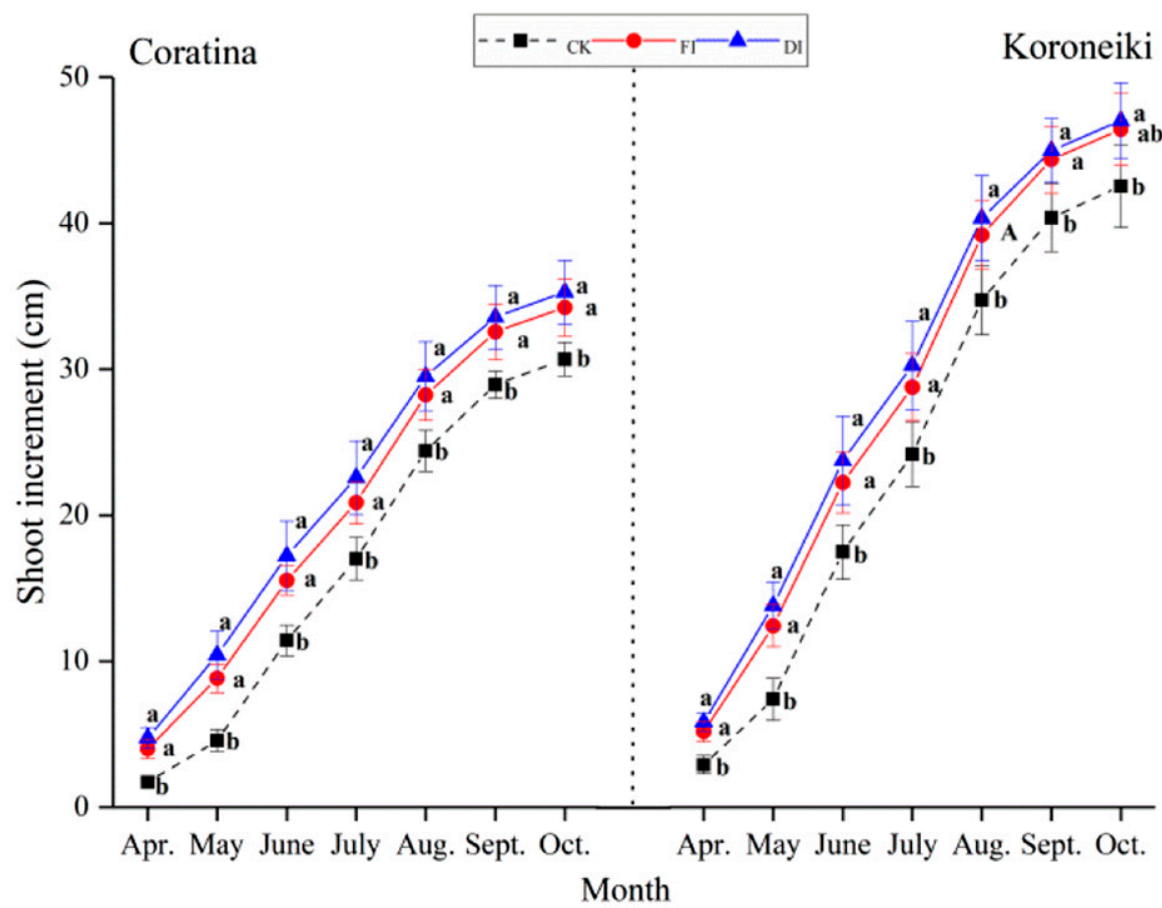

Fig. 2. Effects of different irrigation strategies (rain-fed control (CK), flood irrigation (FI), drip irrigation (DI)] on shoot growth of olive cultivars Coratina (left) and Koroneiki (right) during two crop seasons (2015-16 and 2016-17). Vertical bars indicate SD values, and values with different lowercase letters in the same month are significantly different by Tukey-Kramer honestly significant difference test $(P<0.05) ; 1 \mathrm{~cm}=0.3937$ inch. inflorescence, and water availability is essential to promoting flowers and fruits (Rapoport et al., 2012). A previous study conducted on young olive trees in containers suggested that the lack of water resulted in incomplete flower development and caused a rate reduction of perfect flower (Rapoport, 2014). Another one reported that oil and olive yields can be maximized together in the treatment with increased applied water and can be offset by the reduction in oil content (Grattan et al., 2006). Similar results were found in our study. The olive yields and oil production were consistent with the numbers of inflorescences, flowers (including perfect flowers), and fruits among the treatments: the applications of DI and FI showed significant increase in production compared with $\mathrm{CK}$, and the production in DI was significantly higher than in FI. It indicates that irrigation strategies have a positive effect on olive production. A possible explanation for the higher values of flower number, rate of fruit set, and yields in DI could be due to the lower evaporation rate and higher efficiency of water transportation to the roots than in FI and $\mathrm{CK}$. After that, trees in DI obtained plenty of water to help the differentiation of olive flower bud and reduce the pistil abortion, which contributed to greater potential for olive production. In contrast, FI would be harmful for the root because the air in the soil was squeezed out.

During the stage of fruit oil accumulation, we found that olive fresh fruit weight and pulp rate in DI were lower than those in $\mathrm{CK}$ and FI, which is different from other studies (García et al., 2014; Proietti and Antognozzi, 1996). Considering the highest rates of perfect flower and fruit set, the fruit number of trees in

Table 2. Effects of different irrigation strategies on the number of olive inflorescences and flowers per shoot, and the rates of perfect flowers and fruit set of olive cultivars Coratina and Koroneiki during two crop seasons (2015-16 and 2016-17).

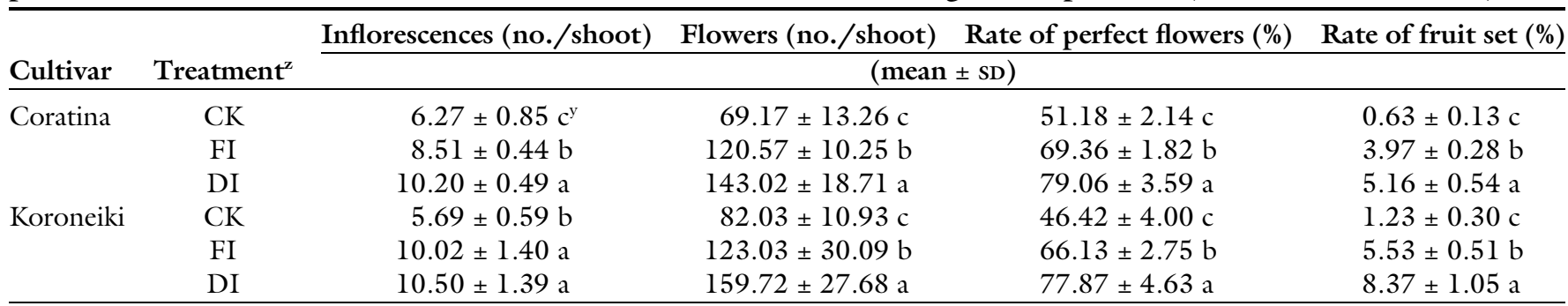

${ }^{\mathrm{z}} \mathrm{CK}=$ rain-fed control, $\mathrm{FI}=$ flood irrigation, $\mathrm{DI}=$ drip irrigation

${ }^{y}$ Values with different lowercase letters in the same row are significantly different by Tukey-Kramer honestly significant difference test $(P<0.05)$. 
DI was expected to be more than those in CK and FI. We also had to consider rainfall without any irrigation starting in late May. Thus, the weight of single fruit, which was composed mainly of pulp, was expected to be the largest in
CK, followed by the fruit in FI, whereas the lowest growth of single fruit occurred in DI. The moisture content of olives in CK was the lowest, with the same result as irrigation in a dry summer in a Mediterranean climate (Nassar, 2009; Proietti and Antognozzi, 1996; Ramos and Santos, 2009). The evapotranspiration was higher than rainfall from April to May in Xichang, causing water shortage for the first fruit growth.
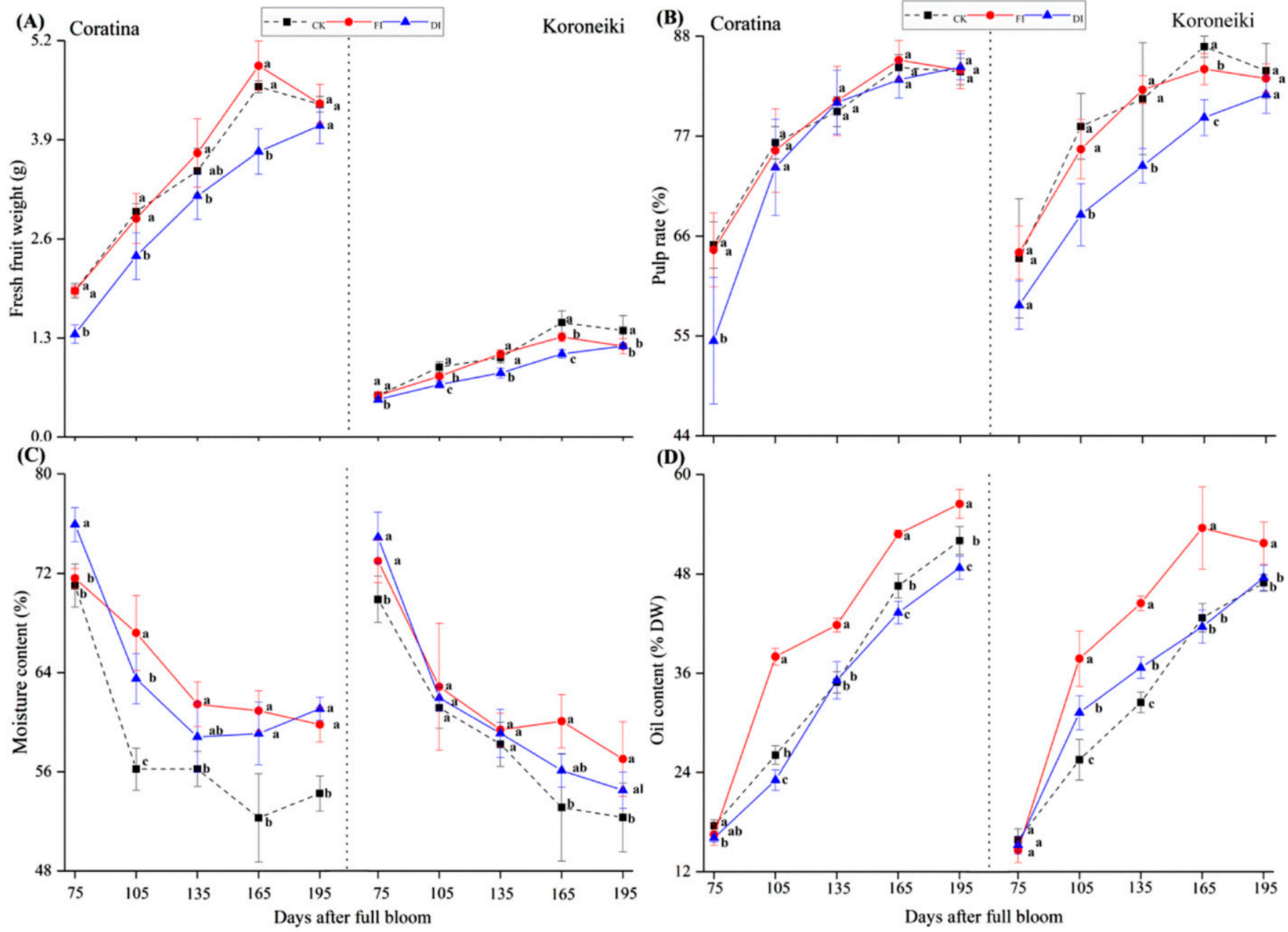

Fig. 3. Effects of different irrigation strategies [rain-fed control (CK), flood irrigation (FI), drip irrigation (DI)] on fruit characteristics of olive cultivars Coratina and Koroneiki during two crop seasons (2015-16 and 2016-17). (A) Fresh fruit weight, (B) pulp rate, (C) moisture content, and (D) oil content. Vertical bars indicate SD values, and values with different lowercase letters at the same days after full bloom are significantly different by Tukey-Kramer honestly significant difference test $(P<0.05) ; 1 \mathrm{~g}=\mathbf{0 . 0 3 5 3} \mathrm{oz}$.

Table 3. Effects of different irrigation strategies on the yields of olive and oil of olive cultivars Coratina and Koroneiki during two crop seasons (2015-16 and 2016-17).

\begin{tabular}{|c|c|c|c|c|c|c|c|}
\hline Cultivar & Treatment $^{\mathrm{z}}$ & $\begin{array}{c}\text { Olive yield [mean } \pm \\
\text { SD }(\mathrm{kg} / \text { tree })]^{\mathrm{y}}\end{array}$ & $\begin{array}{l}\text { Mean increase } \\
\text { from CK }(\%)\end{array}$ & $\begin{array}{c}\text { Mean } \\
\text { increase from } \\
\text { FI }(\%)\end{array}$ & $\begin{array}{c}\text { Oil yield [mean } \pm \\
\text { SD }(\mathrm{kg} / \text { tree })]\end{array}$ & $\begin{array}{l}\text { Mean increase } \\
\text { from CK }(\%)\end{array}$ & $\begin{array}{c}\text { Mean } \\
\text { increase from } \\
\text { FI }(\%) \\
\end{array}$ \\
\hline \multirow{2}{*}{ Coratina } & FI & $16.37 \pm 3.22 b$ & 247.93 & - & $3.70 \pm 0.67 b$ & 231.15 & - \\
\hline & DI & $30.38 \pm 5.68 \mathrm{a}$ & 545.58 & 85.55 & $5.76 \pm 1.05 \mathrm{a}$ & 414.93 & 55.50 \\
\hline Koroneiki & $\mathrm{CK}$ & $3.76 \pm 0.93 c$ & - & - & $0.84 \pm 0.20 \mathrm{c}$ & - & - \\
\hline
\end{tabular}

${ }^{\mathrm{z}} \mathrm{CK}=$ rain-fed control, $\mathrm{FI}=$ flood irrigation, $\mathrm{DI}=$ drip irrigation

${ }^{\mathrm{y}} 1 \mathrm{~kg}=2.2046 \mathrm{lb}$.

${ }^{x}$ Values with different lowercase letters in the same row are significantly different by Tukey-Kramer honestly significant difference test $(P<0.05)$. 
The oil content was the highest in FI and lowest in DI. Depending on the situation of full vegetative growth since April, the potential amount of oil accumulation in FI and DI might be greater than in CK. It should be also noted that olive in DI had the lowest rate of pulp, which perhaps reduced oil accumulation.

\section{Conclusion}

Olive trees in CK gained the lowest values of yields, vegetable growth, flowering and fruit, and moisture content. FI also tended to improve olive production through increasing vegetable growth, flowering and fruit, and oil content. Even though the fruit weight, pulp rate, and oil content in DI were the lowest, our results indicate that DI had the highest values of vegetative growth, flowers, fruit set, and olive and oil yields, and therefore DI from late November to late May was the best irrigation strategy to elevate olive productivity in southwest China.

\section{Literature cited}

Ayoub, S., S. Al-Shdiefat, H. Rawashdeh, and I. Bashabsheh. 2016. Utilization of reclaimed wastewater for olive irrigation: Effect on soil properties, tree growth, yield and oil content. Agr. Water Mgt. 176:163-169.

Bengana, M., A. Bakhouche, J. LozanoSánchez, Y. Amir, A. Youyou, A. SeguraCarretero, and A. Fernández-Gutiérrez. 2013. Influence of olive ripeness on chemical properties and phenolic composition of Chemlal extra-virgin olive oil. Food Res. Intl. 54:1868-1875.

Carrasco-Pancorbo, A., L. Cerretani, A. Bendini, A. Segura-Carretero, T. GallinaToschi, and A. Fernández-Gutiérrez. 2015. Analytical determination of polyphenols in olive oils. J. Sep. Sci. 28:837858 .

Cheng, Z., M. Zhan, Z. Yang, K. Zumstein, H. Chen, and Q. Huang. 2017. The major qualitative characteristics of olive (Olea europaea L.) cultivated in southwest China. Front. Plant Sci. 8:559, doi: 10.3389/ fpls.2017.00559.

China Meteorological Administration. 2017. China climate bulletin 2017 [in Chinese]. 31 Dec. 2018. <http://www. cma.gov.cn>.

Denney, J.O., G.R. Mceachern, and J.F. Griffiths. 1985. Modeling the thermal adaptability of the olive (Olea europaea L.) in Texas. Agr. For. Meteorol. 35:309-327.
Farinelli, D., P. Proietti, G. Papagni, F. Famiani, and P. Guelfi. 2006. Effects of irrigation on olive and productive activity and on oil quality in central Italy. Proc. 2nd Intl. Seminar. Olivebioteq: Biotechnology and quality of olive tree products around the Mediterranean Basin. Marsala-Mazara del Vallo, Italy, 5-10 Nov. 2006. 2:193196.

Fernández, J.E. and F. Moreno. 1999. Water use by the olive tree. J. Crop Prod. 2:101-162.

García, P., C. Romero, and M. Brenes. 2014. Influence of olive tree irrigation and the preservation system on the fruit characteristics of Hojiblanca black ripe olives. Lebensm. Wiss. Technol. 55:403407.

Grattan, S.R., M.J. Berenguer, J.H. Connell, V.S. Polito, and P.M. Vossen. 2006. Olive oil production as influenced by different quantities of applied water. Agr. Water Mgt. 85:133-140.

Gucci, R., E.M. Lodolini, and H.F. Rapoport. 2009. Water deficit-induced changes in mesocarp cellular processes and the relationship between mesocarp and endocarp during olive fruit development. Tree Physiol. 29:1575-1585.

Guo, X., J. Fan, W. Zhu, and D. Yan. 2010. Ecological suitability of olive in Sichuan Province: Fuzzy comprehensive evaluation based on GIS. Shengtaixue Zazhi 29:586-591. (in Chinese).

Hartmann, H.T. 1950. Olive flower-bud formation: Nutrients essential to tree during March and April when flower-buds are forming tests show. Calif. Agr. 4(11):4-16.

Hijazi, A., M. Doghoze, N. Jouni, V. Nangia, M. Karrou, and T. Oweis. 2014 Water Requirement and Water-use efficiency for olive trees under different irrigation systems. 31 Dec. 2018. <https:// www.icarda.org/sites/default/files/ Hijazi-et-al-(2014).pdf>.

International Olive Council. 2016. Olive growing in China. Intl. Olive Council Mkt. Nwsl. 107.

International Olive Council. 2018. World olive oil consumption. Intl. Olive Council, Madrid, Spain.

Liu, Z. and W. Sun. 2013. Trend analysis of precipitation in the Jinsha River basin in China. J. Hydrometeorol. 14:290-303.

Masmoudi-Charfi, C. and N.B. Mechlia. 2008. Changes in olive tree height growth during the first years of cultivation. Adv. Hort. Sci. 22(1):8-12.

Nassar, A. 2009. Comparison of micro irrigation systems for olive trees. Misr J. Agr. Eng. 26:149-169.
Proietti, P. and E. Antognozzi. 1996. Effect of irrigation on fruit quality of table olives (Olea europaea), cultivar 'Ascolana tenera'. N. Z. J. Expt. Agr. 24:175-181.

Ramos, A.F. and F.L. Santos. 2009. Water use, transpiration, and crop $\mathrm{co}^{-}$ efficients for olives (cv. Cordovil), grown in orchards in southern Portugal. Biosyst. Eng. 102:321-333.

Rapoport, H.F. 2014. The reproductive biology of the olive tree and its relationship to extreme environmental conditions. Acta Hort. 1054:41-50.

Rapoport, H.F., S.B.M. Hammami, P. Martins, O. Pérez-Priego, and F. Orgaz. 2012. Influence of water deficits at different times during olive tree inflorescence and flower development. Environ. Expt. Bot. 77:227-233.

Sanz-Cortés, F., J. Martínez-Calvo, M.L. Badenes, H. Bleiholder, H. Hack, G. Llácer, and U. Meier. 2015. Phenological growth stages of olive trees (Olea europaea). Ann. Appl. Biol. 140:151-157.

Shi, Z., W. Sun, Z. Qi, Y. Li, and J. Liu. 2011. On the suitable regions for olive (Olea europaea) growing in China. [in Chinese]. Plant Diversity Resources 33:571-579.

Sofo, A., S. Manfreda, M. Fiorentino, B. Dichio, and C. Xiloyannis. 2008. The olive tree: A paradigm for drought tolerance in Mediterranean climates. Hydrol. Earth Syst. Sci. 4:2811-2835.

Su, C.J., J. Sun, W. Zhu, and L. Peng. 2018. History, distribution, and potential of the olive industry in China: A Review. Sustainability 10:1426, doi: 10.3390/ sul0051426.

Suematsu, M., Y. Wakabayashi, and Y. Ishimura. 2006. Market dynamics and policy reforms in the EU olive oil industry: An exploratory assessment. 98th EAAE Seminar Marketing dynamics within the global trading system: New perspectives. Chania, Crete, Greece. 29 June-2 July 2006. 32:679-686.

Torres, M., P. Pierantozzi, P. Searles, M. C. Rousseaux, G. García-Inza, A. Miserere, R. Bodoira, C. Contreras, and D. Maestri. 2017. Olive cultivation in the southern hemisphere: Flowering, water requirements and oil quality responses to new crop environments. Front. Plant Sci. 8: doi: 10.3389/ fpls.2017.01830.

Vossen, P. 2007. Olive oil: History, production, and characteristics of the world's classic oils. HortScience 42:1093-1100.

Xiao, Q., L. Zhang, L. Zhou, and K. Wu. 2009. Study on olive development in China. American-Eurasian J. Agr. Environ. Sci. 5:414-419. 